\title{
EXPERIENCES OF CHALLENGING HETERONORMATIVITY IN PRE-SERVICE TEACHER TRAINING AT THE UNIVERSITY OF KWAZULU-NATAL: A REFLECTIVE CRITICAL INCIDENT APPROACH
}

\author{
N. Nzimande \\ School of Education \\ Curriculum and Education Studies Discipline \\ University of KwaZulu-Natal \\ Durban, South Africa \\ e-mail: nzimandem2@ukzn.ac.za
}

\section{ABSTRACT}

Pervasion and perpetuation of heteronormativity in the institutions of higher education in the South African context have far-reaching consequences for the LGBTI individuals. Educational research on the preparation of pre-service teachers for teaching in diverse school contexts is scarce. This article highlights the various ways in which heteronormativity manifests in some higher education spaces by drawing on my experiences in teaching a compulsory human rights module offered to final year pre-service teachers at the University of KwaZulu-Natal. Discourses that emerged from students prior to being taught about LGBTI, during the teaching and after they had been taught; which some are argued to be highly subjective and homophobic in nature are discussed through the use of critical incidents and memory-work. This article suggests that teaching about LGBTI does not attempt to 'normalise' non-conforming gender identities, but has the potential to lead to attitude change among some students.

Keywords: higher education, LGBTI, homophobia, sexuality and gender diversity, critical incidents, pre-service teachers

\section{INTRODUCTION}

Heteronormativity may be understood as a socially constructed concept which trivialises lesbian, gay, bisexual, transgender and intersex (LGBTI) identities whilst assuming supremacy of the heterosexual identity (Müller 2015). Heteronormative behaviours and cultures continue to be pervasive in key social institutional spaces, particularly in institutions of higher education. This pervasiveness of heteronormativity has been noted by various studies (Francis and Msibi 2011, 167; Hinrichs and Rosenberg 2002, 63; Johnson 2014, 1264; Mavhandu-Mudzusi and Netshandama 2013, 60; Msibi 2014, 389; Rankin 2005, 20; Rothmann and Simmonds 2015, 119). These studies have found that pre-service teachers who identify with non-normative sexualities: lesbian, gay, bisexual, intersex; as well as non-normative gender identities: transgender, are often met with negative attitudes or violent reactions from other pre-service 
teachers and sometimes lecturers.

The negative attitudes towards LGBTI individuals usually emanate from the normalisation of heterosexuality by the society at large, which often renders non-normative sexualities and non-conforming gender identities as, 'unnatural and unAfrican' (Francis and Msibi 2011, 167); against religious conservative ideologies (Hinrichs and Rosenberg 2002, 63); against the culture of the community (Mavhandu-Mudzusi and Netshandama 2013); vulnerable to harassment (Rankin 2005, 20); the 'other' (Rothmann and Simmonds 2015, 119). In fact, the view by Rothmann and Simmonds is that non-normative sexualities and gender identities are generally seen as deviating from the 'norm'; hence the 'other'.

There has been a plethora of international and local studies covering different aspects of LGBTI individuals at institutions of higher education. These studies focused on the kind of campus climate that is made available for LGBTI individuals (Ellis 2009, 725; Rankin 2005, 20); on attitudes displayed towards LGBTI people, usually by heterosexuals (Hinrichs and Rosenberg, 2002, 62; Mavhandu-Mudzusi and Netshandama 2013, 59); on challenging homophobia (Francis and Msibi 2011, 168; Johnson 2014, 1261); and on teaching about the multiplicity of sexual and gender identities in order to promote safe learning environments for all (Hall 2006, 154; Msibi 2014, 395). Some of the findings of these studies range from the acknowledgement that students in a rural-based university displayed mixed attitudes towards LGBTI students where the negative attitudes had a potential of endangering the LGBTI's lives (Mavhandu-Mudzusi and Netshandama 2013); a need to improve students' awareness about LGBTI (Johnson 2014), to students' responses which indicated willingness to become change agents (Msibi 2014). The findings of these studies are essential for the understanding of the critical incidents that will be highlighted in this article.

The purpose of this article is to highlight the various ways in which heteronormativity may manifest itself in some higher education spaces by drawing on my experiences in teaching a compulsory human rights module at the University of KwaZulu-Natal. Using memory work and critical incidents I wish to highlight the discourses that emerged from pre-service teachers: prior to being taught about sexuality and gender diversities, during the teaching and after they had been taught (post-teaching). Through the use of critical incidents this article showcases the ways in which the received knowledge was negotiated by pre-service teachers during the process of teaching and learning as well as the struggles they experienced as they tried to make meaning of this new knowledge.

As a point of departure, I start off by a brief explanation of what the module entails. Then the critical incidents together with the discourses that emerged prior to, during and after the 
process of teaching and learning are discussed. Pre-service teachers' varied reactions to the teaching of sexuality and gender diversities will also be discussed.

\section{THE MODULE CONTENT}

Education studies 420 is a compulsory module offered to final year Bachelor of Education preservice teachers at the University of KwaZulu-Natal. This module focuses on human and children’s rights, ethics and teacher professionalism. Closely linked to children’s rights, are issues of race, class, gender and sexuality that pre-service teachers also engage with; as a way of preparing them as future teachers to be able to better address issues of diversity in their classrooms. The aspects of sexuality and gender diversities education were introduced in this module three years ago, as an attempt to educate pre-service teachers in sexuality and gender diversities in order to prepare them to be able to teach in diverse contexts.

Different strategies such as problem-solving activities, guided discussions, debates and lectures are used in the teaching of these specific diversities, that is, sexuality and gender. Using problem-solving strategies is a move to encourage pre-service teachers to interrogate their personal biases (Hall 2006, 152) by becoming involved in critical thinking about possible real situations that they may be confronted with when they practise as teachers. Actively engaging pre-service teachers through guided discussions and debates is consciously pushing them to be introspective about their own attitudes and/or behaviours that may privilege heterosexuality over different sexualities, particularly in spaces where heterosexuality is culturally normalised.

The use of various strategies and/or approaches in the teaching of this module is strategic as the lecturers draw from a range of theoretical positions in order to expose students to different ways of thinking (Msibi 2014). These approaches can be argued to have allowed the lecturers of this module to present knowledge as multiple and contested rather than linear. For this article, I draw upon my experiences of teaching in this module, with a particular focus on the sexuality and gender diversity aspects, showing how heteronormative attitudes and sometimes behaviours manifest in some higher education spaces.

\section{METHODOLOGICAL APPROACH}

For this reflective study, the author used critical incidents as an attempt to tap into her experiences of challenging heteronormativity through her practice. A critical incident is not necessarily a traumatic or dramatic event but it is rather an incident that is seen as significant by a particular individual or group. Its significance is highly related to the influence (positive or negative) it may have on the individual's professional and/or personal learning. In essence, 
a critical incident is 'produced by the way we look at a situation... an interpretation of the significance of an event' (Tripp 2011, 8). In other words, the meaning attached to the situation (incident) determines its significance. What Tripp is suggesting is that the judgement that an incident is critical is based on how it is analysed. A critical incident approach is used in this article to highlight discourses that emerged from pre-service teachers prior to being taught, during the teaching and learning and after they had been taught about sexuality and gender diversities. Critical incidents are sometimes referred to as significant events (Keatinge 2002), because of the significance they hold for one's practice. For this reason, the critical incidents analysed in this article are those that have self-defined criticality since they represent moments which were of prominence to the author (Cope and Watts 2000), who (in the process of teaching and learning) was also challenged and questioned by the students about LGBTI.

The critical incidents discussed in this article emanated from the author's active remembering and interpretation of some events that occurred in class. The ability to document elaborated memories of particular events is argued by Anderson and McGrath $(2014,1135)$ to be 'subjectively significant by virtue of being remembered' and as such necessary for the construction of meaning when using memory-work. Therefore, closely linked to the critical incident approach, this article uses memory-work to reflect on the critical incidents which contributed to the problematising and understanding of pre-service teachers' reactions to the teaching of sexuality and gender diversities. The essence of memory-work is that the memories presented are not fabrications but are rather true memories (Onyx and Small 2001, 781). This suggests that ethical considerations of research are also reflected upon and respected when doing memory-work. One is however cognisant of the criticism against the use of memorywork. Whilst the critics of memory-work regard memories as unreliable, the proponents of memory-work are not really concerned about the memories as such; they are rather focusing on the interpretation of the meaning of critical incidents (Crawford et al. 1992, 51). As such, memory work is useful in reflecting on and remembering the scenes or experiences that are important for the researcher/author (Haug 2008, 23). For this reason, the critical incidents presented in this article are not documented anywhere (not resulting from empirical research) but they are drawn from my experiences of teaching pre-service teachers particularly about the sexuality and gender diversities.

Some of the questions that were posed to the pre-service teachers in order to initiate the discussions and/or debates in class ranged from: What is your understanding of lesbian, gay, bisexual, transgender, intersex (LGBTI)? And some were reflective questions for example: Am I homophobic? In what way/s or to what extent have I been homophobic to other students? 
What are the roots of my homophobia? What can teachers do to improve the lives of LGBTI? In some instances the students had to respond individually to the questions, whilst in other instances they were given opportunities to engage with their 'neighbours' to share their responses before reporting back to the larger group (whole class). I wrote as many responses as I could on the board to be used as reference for later whole group discussions.

\section{EMERGING DISCOURSES FROM PRE-SERVICE TEACHERS' REACTIONS TO BEING TAUGHT ABOUT NON-NORMATIVE GENDER IDENTITIES AND SEXUALITIES}

The two aspects of the module that are the focus of discussion in this article, were taught after the pre-service teachers had thoroughly engaged with human rights (with reference to the three human rights instruments: United Nations Declaration of Human Rights, African Charter on Human and People’s Rights and the South African Bill of Rights), children's rights and race. As a point of departure, terminologies related to gender were unpacked alongside with those related to sexuality. For example, differences between sex, gender and sexuality were highlighted as well as sexism, heterosexism, heteronormativity and homophobia. This was purposefully done to clear any misconceptions in this regard, and also to enable the students to actively engage in the discussions using the acceptable terminology.

\section{EMERGING DISCOURSES PRIOR TO BEING TAUGHT: DENIAL, HATRED AND MISINFORMATION}

The first incident that took me by surprise was when I posed what I thought was a straightforward question to pre-service teachers and instead received responses that for a moment left me in a state of confusion. The question that was asked, was: 'What is your understanding of lesbian, gay, bisexual, transgender, intersex (LGBTI)?' This question was meant to draw from pre-service teachers their prior knowledge of these terms as an attempt to understand their cognitive understanding of LGBTI. It is important to note that some of the responses were highly emotive. Such responses can be said to have revealed a different kind of knowledge, a bitter knowledge which is explained by Jansen (2008), to be the knowledge (spoken or unspoken) which is transmitted through generations. This knowledge would have been caught up by pre-service teachers in their early socialisation processes from different institutions (home, church, school etc.). What was more troubling was the realisation that these highly reactive responses had been untouched through years of teacher education since the students were in their fourth/final year of study. Here are some of the responses: 
There is no such thing - they are not born with it.

Oh it's just fashion.

These people omathandazinto - they are just confused.

These people bayanginyanyisa - I despise them.

This gay/lesbian thing is for white people - Black people are just copy cats.

They are people just like us.

This incident highlights some of the ways in which heteronormative attitudes and/or behaviours are normalised at the expense of others and it clearly reveals the inherent homophobic attitudes towards LGBTI individuals. Firstly, in the students' perceptions there is the notion that nonnormative genders and sexualities are 'abnormal' or they are unnatural since they are not born with it. By implication, this means that there are forms of sexualities and gender that are considered to be 'normal' but not the LGBTI forms. Secondly, the notion that these forms of genders and sexualities are nothing but a passing phase - fashion comes and goes. Thirdly, the notion of referring to LGBTI individuals as 'these people' implies some sort of hatred coupled with denial, which usually stem from a strong tendency of othering. The fact that they are being referred to as 'omathandazinto' (people who like things, especially material things/ or people who are opportunists) and 'confused' - indicates that they are not fully human or capable of making rational decisions. Fourthly, a very clear notion and statement of hatred and homophobia - 'bayanginyanyisa' means that one has very strong feelings of hatred (hating with a passion). Finally, there is the notion that homosexuality is associated with a particular race which is seen to be pushing forward the agenda that homosexuality is un-African. On a different tone, there were comments which were neither highly charged nor homophobic. From the statement 'they are people just like us', one can argue for an attitude of acceptance to have been revealed.

The stereotypes and maybe distortions that pre-service teachers carry with them were clearly noted in most of their initial responses which can be said to have been subjective, homophobic and highly problematic. The issue of homosexuality being un-African (Msibi 2011, 63) and/or unnatural (Epprecht 2010, 11) has been interrogated and found to be untrue. The responses discussed above demonstrate the kind of 'bitter knowledge' and received knowledge (which are often stereotypical) about LGBTI individuals that the pre-service teachers carry with them into the classroom spaces. These kinds of articulations perhaps are strategically made in order to incite other pre-service teachers to act negatively towards LGBTI. In this way the articulations are no longer influenced by personal experiences of pre-service teachers only but become shaped by the public personae that pre-service teachers want to create 
in front of others, and as such concretise a particular discourse (Rind and Benjamin 2001). Through this incident the challenge for me then was: how do I (through my teaching) destabilise the status quo which invariably promotes heteronormativity? How do I challenge the students' homophobic articulations or attitudes without appearing to be disrespectful of pre-service teachers and at the same time raise a flag for social justice?

As mentioned earlier, various theoretical approaches underpin the teaching of the module as an attempt to use diverse approaches to confront oppression which is argued by Kumashiro (2002) to be multi-layered. Hence one of the approaches explicitly used in the module was Kumashiro's (2002) anti-oppressive pedagogy since the lecturers in the module were largely positioned as activists. Nevertheless, it appeared in one of our pre-planning meetings that some lecturers were fearful to engage with the content on sexuality and gender diversities. It later turned out that the fear really stemmed from anticipating the kind of questions that the students would ask and not necessarily from the type of content that they were to engage with. This fear is justified by what Kumashiro $(2002,68)$ notes as 'the unknowability involved in teaching' which he claims to require constant interrogation of one's own practice with the aim of looking 'beyond what we already know'.

\section{EMERGING DISCOURSES DURING THE TEACHING AND LEARNING PROCESS: HUMAN RIGHTS AND HUMANENESS}

A tactful approach was then necessary if the homophobic utterances or behaviour of some preservice teachers were to be rigorously troubled in a manner that would not in any way compound 'the struggles of lesbian and gay pre-service teachers' (Hames 2007, 22). Therefore, class activities that drew connections from pre-service teachers' lived experiences to the theorising about the sexuality and gender diversities within the classroom confines were designed. Activities such as case scenarios, class discussions, debates and so on were deliberately used to foster dialogue among pre-service teachers in an attempt to create numerous opportunities to help pre-service teachers trouble their received knowledge as they struggle to accommodate their new knowledge and understanding of diverse sexualities.

The second incident I wish to share occurred during the teaching and learning process after an intensive discussion about the theorisation of gender and sexuality, showing a close link to human rights and human rights violations of both women and of LGBTI individuals. Pre-service teachers were asked to work in pairs in order to reflect on the content that had been taught and learned. The reflective questions were: Am I homophobic? In what way/s or to what extent? What are the roots of my homophobia? The instruction was that pre-service teachers 
should take turns to listen to each other's response and then they would report back on each other's story. The idea was to have pre-service teachers to listen to their stories being told by someone else; in that way it would force them to listen to their own stories and reflect upon them. Of course, because of large numbers in class, not all pre-service teachers got to hear their stories.

From this exercise quite a number of pre-service teachers categorically responded 'yes' to the main question and the claim was that they just do not want to talk about 'this gay stuff', citing religious reasons as the root of their homophobia. On the contrary, some pre-service teachers (very few) strongly said 'no' and the claim was that they have friends who are either gays or lesbians, so they already associate with them. Also, other pre-service teachers hesitantly said 'no' to being homophobic and the claim was that they think they are tolerating 'these people', which means that they recognise them as human beings but they don't have to love them.

This incident reveals the explicit and implicit ways in which homophobia is demonstrated in the spaces of higher education which is known to be culturally unresponsive to sexuality and gender diversity. Firstly, that some pre-service teachers are unashamedly homophobic and use their religion as the bases of their arguments, quoting bible verses which they claim to be against homosexuality is problematic as it 'dehumanises people and makes them feel that who and what they are, is sinful' (Msibi 2013, 69). Secondly, the thinking that, because one has a friend or knows someone who is either gay or lesbian, then that person is automatically non-homophobic shows lack of understanding of the deep-seated seeds of homophobia as well as lack of reflective skills. Lastly, the fact that other pre-service teachers view themselves as nonhomophobic, yet the language they use is not inclusive. The use of 'these people', and 'them' depicts some kind of superiority which is looking down upon the 'other' group. This is what Rothmann and Simmonds $(2015,118)$ call the 'objectification of the homosexual'. On the other hand, these pre-service teachers can be said to be using a human rights discourse in that they refer to association, tolerance and recognition of other human beings. However, they also present a contradictory view when they refuse to love 'them'. I therefore argue that the use of such language is highly homophobic and discriminatory towards people who do not conform to the conventional expectations of heterosexuality. Moreover, this language is inhumane and it was clearly marginalising the LGBTI. Therefore, the need to address not only what was said by some students (homophobic articulations) but also what was not said (particularly by those students who identify as LGBTI).

Scholars of human rights, for example Linde and Arthur (2015) have critiqued the human 
rights-based approach as creating a 'grand narrative' which seems to valorise the American and European norms and values, hence purporting a global history which fails to take the importance of context into account. Moreover, the human rights-based approach seems to prioritise the individual over the communal or cultural rights and as such, likely to influence students to value individual choices as opposed to shared (social) responsibilities. For example, it was easy for students to individually express their views which were often shifting their responsibility and/or accountability away from dealing with sexuality and gender diversity.

\section{EMERGING DISCOURSES AFTER BEING TAUGHT (POST-TEACHING): POWER, AWARENESS, AND CHANGE AGENTS}

The final session on sexuality education is really about interrogating further the pre-service teachers' readiness to deal with diversity in relation to sexuality and gender as future teachers. How well-prepared are pre-service teachers to create enabling environments which will cater for all learners irrespective of their diversities? The last incident occurred when a teaching resource, a DVD, called 'We all count' was used to show the life stories of lesbian and gay preservice teachers and school learners. In this DVD they shared their experiences of homophobia in schools and on university campuses. A range of sexualities was represented by the participants (in the video) as there were also school teachers who were featured in the video. The overarching message that the gay and lesbian participants put forward was that of acceptance; they were yearning for acceptance by friends, parents and their communities. All the other participants seemed to agree on the same message that anyone has the ability to destabilise heteronormativity in whatever form or shape it appears to be, e.g. homophobia and heterosexism. One of the participants was a pastor, a church leader who spoke openly about how Christianity needs to be accepting of sexuality and gender diversities.

The reason why I highlight this incident is because I was very moved by the stories shared by the gay and lesbian participants in the video. These stories pushed me out of my comfort zone and I really felt empowered and excited that I had found a resource that I could use to challenge the stereotypes, homophobia and heteronormativity that are displayed by the preservice teachers. I have shown elsewhere how the 'self' was transformed through engaging with the content on LGBTI-identifying individuals (Nzimande 2015, 78). Therefore, the pre-service teachers, after watching the video were given a few questions to reflect and then debriefing was done. Here are some of the questions that were given to pre-service teachers for reflection:

What are your thoughts/feelings about the video?

What are the fears that people have about accepting gay and lesbian people? 
Think about ways in which we as individuals and teachers can be allies of gay and lesbian people, or be more open to ideas of fluidity.

What can teachers do to improve the lives of gay and lesbian people?

As can be expected, the pre-service teachers' responses to the reflective questions were extremely varied. Here are some of the responses from pre-service teachers:

I will disown or kill my child - I will beat him or her until s/he stops being gay or lesbian.

If they are learners in my class, I will read them a bible every day to remind them what they are doing is a sin against God's will.

I still maintain that these people are lost souls who need a prayer intervention.

I don't want any gay sitting next to me in lecture rooms - I don't even associate with them at res.

This incident highlights the unchanged mentality of some pre-service teachers even after all the class discussions that had transpired and after they had watched the video. Utterances such as the ones presented above may be linked to pre-service teachers' reluctance to deal with the real issues of confronting homophobia and/or heteronormativity in their spaces of interaction with others and particularly with their learners as future teachers. It is important to note that some people may easily hide behind their religious convictions and violence in order to avoid dealing with pertinent issues due to fear. This issue of fear of being proactive in addressing LGBTI matters or homophobia in general has also been suggested by Francis and Msibi $(2011,168)$ when they realised that students in their study were not being proactive in raising awareness about LGBTI because of fear. I then argue that this fear should not be understood as a personal decision, it is systematic. For instance, the student who claimed that he would kill his own child, was asked to explain 'why'. He then mentioned that the child would not only be a disgrace to him or his immediate family but to the whole clan. In this case it was clear that it was not going to be easy for students to quickly unlearn all the things they had been systemically socialised into for their entire life of schooling and in their homes as well. These are the struggles that the students were involved in, trying to unlearn the received (previous) knowledge in order to better position themselves in relation to the new knowledge.

Another important point to highlight from the statements made by a few students is the framing of LGBTI individuals as sinners who need some sort of intervention. This framing is not only heteronormative but also introduces power as well.

I will read them a bible every day to remind them that what they are doing is a sin against God's will.

I still maintain that these people are 'lost souls' who need a prayer intervention. 
The inherent assumptions in these statements, are firstly, that heterosexuals are positioned as having authority and power to speak to God on behalf of the LGBTI individuals. In essence, these students do not only reveal their hatred and fear that come from their early socialisation, but they also put out their feelings that are obviously reactive as if they are asking for reassurance and leadership. Secondly, the notion that a person is perceived as doing something wrong if s/he does not subscribe to the normative gender identities and sexualities is very worrying. What kind of strategies can be employed by teacher educators to destabilise this perpetual normalisation of heterosexuals? It was apparent that even after being taught about gender identities and sexuality education, some pre-service teachers deliberately wanted to 'hang-onto' their prior socialisation which is subjective and homophobic. Such actions may have been influenced by the fact that these students were avoiding 'cognitive dissonance' (Johnson 2014, 161), that they were not ready to question their family beliefs or their own assumptions in order to embrace the new knowledge (learning). In a study, Richardson (2004, 160), reflects on the student participants who were resistant to any kind of knowledge which seemed to be in conflict with their belief system. Therefore, getting pre-service teachers to express the underlying feelings and their unhappy emotions is a necessary part of learning if they are to have positive attitudes towards LGBTI-identifying individuals.

There were positive responses from quite a number of students. I will only recount a few examples:

Maybe I was too judgemental - I now feel sorry for them - it must be really hard on them.

As teachers we are role models to our learners - therefore we need to be careful of our own actions so as not to discriminate against but accept them as they are.

I was really touched by the stories of the learners in the video. I want to bring about change in my classroom as a future teacher but I am afraid of being labelled as promoting unbecoming behaviour.

It was refreshing and very encouraging to note that most students, after watching the video were at a high level of discomfort and others were very emotional. These expressions of discomfort and emotions were indications that pre-service teachers were being reflective, perhaps about their unhappy socialisation or their actions and/or attitudes towards LGBTI-identifying individuals. The point I am trying to make here is that homophobia is about how we think and feel about ourselves, whether we are heterosexual or not. The discourse that emerged from their accounts was that of acceptance, change and willingness to do something. For these students, it was clear that they were not only reflective about the part they might have played in promoting or engaging in homophobic behaviours; but they were also becoming aware of their 
responsibilities as future teachers. This kind of learning is precisely the aim of the module in teaching about LGBTI / gender identities and sexual orientation, challenging students to think about and consider the various roles they would have to play as future teachers; not only in their respective classrooms but in the wider community. It was clear that these students were anticipating becoming change agents (Johnson 2014, 1262), who may (of course, with support of other stakeholders) transcend the 'anti-work' and be able to do the 'ally-work' (Clark 2010, 707). Allies are people who are not just concerned about being anti-homophobic or maybe antiheterosexist but are very much willing to be actively involved in changing other people's attitudes towards LGBTI individuals (Clark 2010, 707).

A paradigm shift appeared to have happened in terms of these students' thinking and talking about LGBTI individuals. This kind of shift is likely to translate to not only acceptance of but respect for LGBTI individuals. I therefore argue that these positive accounts from students were indicative that their prior knowledge and/or behaviour (heteronormativity) had been disrupted or challenged and they were now open to further learning (Meyer 2007, 26). Such students can be said to have been able to be critical of their own actions. However, as indicated by some students, they were sceptical of publicly acknowledging the non-normative gender identities and sexualities because of the fear of being labelled as promoters of 'unbecoming behaviour'. Again, fear was seen as preventing pre-service teachers from doing what is socially right and just. It is this fear that may hinder the pre-service teachers in their process of 'being and becoming' (Msibi 2014, 407).

The debriefing process was necessary at the final session of teaching about gender identities and sexual orientation. In this process it was imperative to draw students' attention to gender and its operation. For example, power relations between the genders, vertical and horizontal oppression between and within the genders and so on. The reflective question that was asked, was: In what ways do we experience homophobia even without being gay or lesbian? By this question I am in no way indicating that homophobia is acceptable. The idea here was to show students that there are very strong links between gender and sexuality.

Students' responses were not surprising; they were able to draw from their lived experiences and gave accounts of patriarchy and relating it to heteronormativity. These are issues of exclusion because of jealousy either between genders or within a particular gender. The discourse focused largely on the power relations between males and females in general, between spouses/partners in particular, and how women are marginalised even when they happen to hold high positions. It also addressed the way in which females (girls and women) are socially excluded. Students (making reference to the South African Constitution) 
highlighted the injustice that comes with socially excluding some groups which are often given lower status than the others. These students' responses presented a platform for me to draw connections to the heteronormative attitudes and/or behaviours that some of them had exhibited prior to, during and after being taught about LGBTI-identifying individuals and how they themselves had also been articulating an 'exclusion' agenda. At that moment, it seemed that some students had their 'Aha' moments. It seemed that they were only understanding the bigger picture of why they had to engage in the teaching and learning about the sexuality and gender diversity; because, as some said in conclusion, 'at the end of the day maam, we are all human'.

\section{CONCLUSION}

The above discussion has highlighted that heteronormative attitudes and/or behaviours are largely normalised in some spaces of the institution of higher education. The critical incidents highlighted in this article and the literature clearly showed the pervasive nature of homophobia on the campus. This article outlined the discourses that emerged from students prior to being taught about non-normative sexualities and gender identities, the discourses that emerged during the teaching, as well as after students were taught about these issues. Through the discussion of the critical incidents the article has shown how the students were in constant negotiation and/or struggle in an attempt to match their received (prior) knowledge to the new knowledge they were being taught about LGBTI or non-normative sexualities/gender. The article argues that for some students, their public personas (how they are viewed by their friends/classmates) has a huge influence in terms of how they will behave towards the LGBTI individuals - the 'macho' façade. The article then concludes by suggesting that pedagogical instruction that is centred on LGBTI does not only raise awareness or attempt to 'normalise' the gender non-conforming identities, but it has the potential to lead to attitude change among some students.

From the incidents analysed in this article it was clear that the teaching about sexuality and gender diversity was not received by students in a similar way, hence their being at different levels of understanding and perhaps willingness to change their ways of doing things. What more can be done to reach a stage where not only some, but most or at best, all pre-service teachers can have a change in attitude toward LGBTI-identifying individuals? How can the preservice teachers who are being prepared for both their educational and professional life demonstrate that they may, in some cases hate some of those whom they are teaching? The responsibility clearly lies with the designers of the teacher education curriculum. A major question perhaps is whether the curriculum truly engages or not with all the underlying confusion or bitter knowledge that students bring to class? 


\section{LIMITATION OF THE STUDY}

The critical incidents described in this article were drawn from one of the four groups of the final year pre-service teachers that I was teaching. The class had about 200 students. Therefore, the students' responses should be interpreted with this limitation in mind, that they are not representative of all the final year pre-service teachers' views. Given the teaching time limitations, the module may not have adequately allowed pre-service teachers to be critical in troubling their own sexualities.

\section{RECOMMENDATION}

There clearly is a need of a transformative curriculum which will not only introduce but engage pre-service teachers with sexuality and gender diversities at all levels, not only when they are at their exit level. Such a curriculum is highly likely to provide pre-service teachers with varied and wider opportunities to reflect on their thinking, attitudes and behaviour towards LGBTI individuals. Therefore there is a need for a transformative curriculum which is underpinned by a critical human rights pedagogy which not only allow students to be critical about their decisions and actions but to also be aware of their impact on others particularly the marginalised groups.

\section{REFERENCES}

Anderson, Katie and Laura McGrath. 2014. Exploring embodied and located experience: Memory-work as method for drug research. International Journal of Drug Policy 25(6): 1135-1138. doi: 10.1016/j.drugpo.2014.08.008.

Clark, Caroline T. 2010. Preparing LGBTQ-allies and combating homophobia in a US teacher education program. Teaching and Teacher Education 26(3): 704-713.

Cope, Jason and Gerald Watts. 2000. Learning by doing. An exploration of experience, critical incidents and reflection in entrepreneurial learning. International Journal of Entrepreneurial Behaviour and Research 6(3): 104-124.

Crawford, June, Susan Kippax, Jenny Onyx, Una Gault and Pam Bentom. 1992. Emotion and gender: Constructing meaning from memory. Thousand Oaks, CA, US: Sage Publications Inc.

Ellis, Sonja J. 2009. Diversity and inclusivity at university: A survey of the experiences of lesbian, gay, bisexual and trans (LGBT) students in the UK. Higher Education 57(6): 723-739.

Epprecht, Marc. 2010. Understanding homophobia in Africa today. Perspectives 4(10): 10-15.

Francis, Dennis and Thabo Msibi. 2011. Teaching about heterosexism: Challenging homophobia in South Africa. Journal of LGBT Youth 8(2): 157-173.

Hall, Horace R. 2006. Teach to reach: Addressing lesbian, gay, bisexual, and transgender youth issues in the classroom. The New Educator 2(2): 149-157.

Hames, Mary. 2007. Sexual identity and transformation at a South African university. Social Dynamics 33(1): 52-77.

Haug, Frigga. 2008. Memory-work: ‘A detailed rendering of the method for social science research'. In Dissecting the mundane: International perspectives on memory-work, ed.Adrienne E. Hyle, 
Margaret E. Ewing, Diane Montgomery and Judith Kaufman, 21-41. Lanham, Maryland (USA): University Press of America.

Hinrichs, Donald W. and Pamela J. Rosenberg. 2002. Attitudes toward gay, lesbian, and bisexual persons among heterosexual liberal arts college pre-service teachers. Journal of Homosexuality 43(1): 61-84.

Jansen, Jonathan. 2008. Bearing Whiteness: A pedagogy of compassion in a time of troubles. Education as Change 12(2): 59-75.

Johnson, Bernadette. 2014. The need to prepare future teachers to understand and combat homophobia in schools. South African Journal of Higher Education 28(4): 1249-1268.

Keatinge, Diana. 2002. Versality and flexibility: Attributes of the Critical Incident Technique in nursing research. Nursing and Health Sciences 4: 33-39.

Kumashiro, Kevin. 2002. Troubling education: Queer activism and anti-oppressive pedagogy. New York: RoutledgeFalmer.

Linde, Robyn and Mikaila M. L. Arthur. 2015. Teaching progress: A critique of the grand narrative of human rights as pedagogy for marginalised students. Radical Teacher: A Socialist, Feminist, and Anti-Racist Journal on the Theory and Practice of Teaching 103: 26-37. doi: 10.5195/rt.2015.227.

Mavhandu-Mudzusi, Azwihangwisi Helen and Vhonani Olive Netshandama. 2013. The attitudes of preservice teachers towards the lesbian, gay, bisexual, transgender and intersex community: A case of a South African, rural-based university. African Journal for Physical, Health Education, Recreation and Dance, Supplement 1(1): 56-66.

Meyer, Elizabeth J. 2007. But I'm not gay: What straight teachers need to know about queer theory. In Queering straight teachers: Discourse and identity in education, ed. Nelson M. Rodriguez and William F. Pinar, 15-29. New York city: Peter Lang.

Msibi, Thabo. 2011. The lies we have been told: On (homo) sexuality in Africa. Africa Today 58(1): 54-77.

Msibi, Thabo. 2013. Queering transformation in higher education. Perspectives in Education 31(2): 6573.

Msibi, Thabo. 2014. The teaching of sexual and gender diversity issues to pre-service teachers at the university of KwaZulu-Natal: Lessons from student exam responses. Alternation, Special Edition 12: $385-410$.

Müller, Alexandra. 2015. Strategies to include sexual orientation and gender identity in health professions education. African Journal of Health Professions Education 7(1): 4-7.

Nzimande, Nomkhosi. 2015. Teaching pre-service teachers about LGBTI issues: Transforming the self. Agenda 29(1): 74-80.

Onyx, Jenny and Jennie Small. 2001. Memory-work: The method. Qualitative Inquiry 7(6): 773-786.

Rankin, Susan R. 2005. Campus climates for sexual minorities. New Directions for Student Services 2005(111): 17-23.

Richardson, Eric M. 2004. A ripple in the pond: Challenging homophobia in a teacher education course. Education as Change 8(1): 146-163.

Rind, Bruce and Daniel Benjamin. 2001. Effects of public image concerns and self-image on compliance. The Journal of Social Psychology 134(1): 19-25.

Rothmann, Jacques and Shan Simmonds. 2015. 'Othering' non-normative sexualities through objectification of 'the homosexual': Discursive discrimination by pre-service teachers. Agenda 29(1): 116-126.

Tripp, David. 2011. Critical incidents in teaching (Classic Edition): Developing professional judgement. London and New York: Routledge. 